DARIA MAZUR

Uniwersytet Kazimierza Wielkiego

\title{
Kino jidysz na ziemiach polskich do wybuchu drugiej wojny światowej - konteksty społeczno-polityczne i kulturowe
}

Images

vol. XVII/no. 26

Poznań 2015

ISSN 1731-45OX

Roman Włodek rozpoczyna monografię przybliżającą polskiemu odbiorcy historię żydowskiego kina od rozważań na temat trudności $\mathrm{w}$ jego definiowaniu[1]. Podobnie jak w przypadku teatru diaspory, za jeden z kluczowych elementów pozwalających wyróżnić to zjawisko kulturowe uznawany jest język[2]. Pojęciem kina jidysz obejmuje się więc filmy zrealizowane w języku jidysz przez twórców pochodzenia żydowskiego, przedstawiające treści, które dotyczą społeczności diaspory[3]. Powstawały one w latach 1910-1950 głównie tam, gdzie żyło wielu Żydów - w USA i Polsce oraz w Rosji, a następnie do lat 30. XX wieku - w Związku Sowieckim, ale sporadycznie też w innych państwach europejskich. Rozważając zmiany zachodzące w kinie jidysz na ziemiach polskich oraz jego elementy swoiste, warto uwzględnić ich związek z zewnętrznym kontekstem społeczno-politycznym i ocenić, $\mathrm{w}$ jakim stopniu warunkował on produkcję powstającą przede wszystkim dla hermetycznej społeczności żydowskiej. Kluczowe dla tej twórczości - od jej początków do wybuchu drugiej wojny światowej motywy, wątki tematyczne, schematy fabularne miały też swe źródła w wewnętrznych tendencjach kulturowo-ideowych diaspory w Polsce: tradycyjnej, związanej z judaizmem i językiem jidysz; syjonistycznej, usiłującej wskrzesić państwo Izrael i odwołującej się do języka hebrajskiego; bundowskiej - lewicowej, wspierającej laicką kulturę jidysz i przeciwnej syjonizmowi, oraz asymilacyjnej - otwartej na kulturę i język polski. Rozważenie wyszczególnionych szerokich kontekstów pozwala na określenie wpływu czynników dominujących oraz zasięgu oddziaływania pozostałych na rozwijające się do drugiej wojny światowej na ziemiach polskich kino jidysz[4].

[1] Zob. R. Włodek, Na początku było Le’chajim. Bardzo krótka historia kina żydowskiego, Towarzystwo Społeczno-Kulturalne Żydów, Szczecin 2013, s. 9. Wyjątkiem od tej definicji jest zrealizowany w Palestynie przez Aleksandra Forda film dźwiękowy Sabra, w którego dialogach nie używano jidysz.

[2] Zob. M. Bułat, W poszukiwaniu teatru „żydowskiego": Zygmunt Turkow, w: Antreprener. Ksiega ofiarowana profesorowi Janowi Michalikowi w 70 . rocznice urodzin, red. J. Popiel, Wydawnictwo UJ, Kraków 2009, s. 585-586; E.A. Goldman, Visions, Images, and
Dreams. Yiddish Film Past and Present, UMI Research Press, AnnArbor 1983, s. XVII.

[3] Zob. R. Włodek, op. cit.

[4] Uzasadnieniem dla podjęcia tej problematyki jest fakt, że pionierska monografia Natana Grossa Film żydowski $w$ Polsce, ze względu na obfitość materiału, prezentowała wybrane elementy kontekstów społeczno-politycznych i kulturowych. Książka Romana Włodka traktuje zaś o bardzo szerokim spektrum żydowskiej twórczości filmowej (od powstającej w USA po realizowaną w Związku Sowieckim), stąd 
Element ludowości i egalitaryzmu wpisany był w kulturę Żydów aszkenazyjskich. Film opierał się także na tych czynnikach i doskonale nadawał do prezentowania opowieści o biedzie, tułaczce, nieszczęśliwej miłości i śmierci. Sprzyjało to powstawaniu na ziemiach polskich niemych filmów żydowskich, które obrazowały kondycję odbiorców przez odwołania do wspomnianych kategorii. Film ten w pionierskim okresie wyrastał też z twórczości dramaturgicznej w jidysz, podejmującej problematykę obyczajową, społeczną diaspory, wzbogaconą o elementy religijne i folkloru. Domeną literatury i teatru żydowskiego było podtrzymywanie własnej kultury, podkreślanie tożsamości. Bujny rozwój piśmiennictwa w jidysz nastapił od lat 6o. XIX wieku do wybuchu pierwszej wojny światowej (okres klasyków: Mendełe Mojchera Sforima, Szolema Alejchema, Icchoka Lejba Pereca)[5]. Najczęściej przenoszono na ekran jednak popularne sztuki Jakuba Gordina, Zalmena Libina i Heimana Meisela, co miało związek z czynnikiem ekonomicznym, gdyż były to nierzadko gotowe przedstawienia realizowane przez twórce teatru rodziny Kamińskich - Abrahama Izaaka Kamińskiego[6]. Wczesne filmy (np. Okrutny ojciec, Dziki człowiek, Mirele Efros, Sierota Chasia, Macocha, Ubój, Bigamistka, Córka kantora) przedstawiały żydowskie życie rodzinne i związane z nim konflikty, dylematy moralne. W okresie niemym podjęto też pierwsze próby połączenia filmowej opowieści z kontekstem mistycznym, z żydowską duchowością (ekranizacja sztuki Jakuba Gordina Bóg, człowiek i szatan, 1912, inspirowanej Księgą Hioba i Faustem, oraz niema wersja Ślubowania, 1924, w reż. Zygmunta Turkowa). Tendencja ta znalazła jednak swe najpełniejsze rozwinięcie dopiero w dźwiękowych przypowieściach filmowych $z$ lat 30.

Oryginalnym i odosobnionym w kinematografii jidyszowej zjawiskiem były podjęte jeszcze w epoce kina niemego próby ekranizacji utworów literackich związanych z problematyką żydowską, napisanych przez polskich autorów (Meir Ezofowicz, 1911, wg powieści Elizy Orzeszkowej i Sąd boży, 1911, wg dramatu Sędziowie Stanisława Wyspiańskiego). Natomiast po kilkuletniej przerwie spowodowanej pierwszą wojną światową i początkowo bardzo niepewną kondycją żydowskiej mniejszości w niepodległej Polsce (np. dramatyczne doświadczenia pogromów 1918-1919[7]) twórczość filmowa w jidysz odrodziła się, przynosząc ciekawe próby rozwijania wątków nawiązujących do polskiego

też specyficzne uwarunkowania kina jidysz w Polsce nie mogły być w niej analizowane szczegółowo. Zob. N. Gross, Film żydowski $w$ Polsce, tłum. A. Ćwiakowska, Rabid, Kraków 2002; R. Włodek, op. cit.

[5] Kolebką nowoczesnej literatury jidysz w XIX wieku była Polska w granicach sprzed rozbiorów. Zob. Ch. Shmeruk, Historia literatury jidysz. Zarys, Ossolineum, Wrocław-Warszawa-Kraków 1992, s. 7.

[6] Zob. Państwowy Teatr Żydowski im. Ester Rachel Kamińskiej. Przeszłość i teraźniejszość, oprac. S. Gąs- sowski, Wydawnictwo Naukowe PWN, Warszawa 1995, s. 57-61.

[7] Do zamieszek doszło w Galicji Zachodniej, w Krakowie, Kielcach, we Lwowie i w Pińsku. Zob. A. Żbikowski, Żydzi, Wydawnictwo Dolnośląskie, Wrocław 1997, s. 195-197; Najnowsze dzieje Żydów w Polsce. W zarysie (do 1950 roku), red. J. Tomaszewski, oprac. J. Adelson, T. Prekreowa, J. Tomaszewski, P. Wróbel, Wydawnictwo Naukowe PWN, Warszawa 1993, s. 139. 
kontekstu. Druga połowa lat 20. to okres, w którym w społeczności żydowskiej zaznaczyły się tendencje asymilatorskie, mające swe źródła jeszcze w XIX wieku[8]. Ich wyrazem są: Jeden z trzydziestu sześciu (Lamedwownik, 1925) w reżyserii Henryka Szaro i W lasach polskich (1929) w reżyserii Jonasa Turkowa według popularnej powieści Josefa Opatoszu W lasach polskich i Żydzi walcza o niepodległość Polski (Rok 1863). Pierwszy z filmów, którego akcja osadzona jest w okresie powstania styczniowego, to historyczno-mistyczna opowieść o cadykach poświęcających życie, by ratować lokalną społeczność. Scenariusz drugiego filmu nawiązywał do problematyki pozytywizmu - podejmował kwestie postępu, emancypacji, zbliżenia do polskiej kultury, asymilacji narodowej i współdziałania $\mathrm{w}$ walce $\mathrm{z}$ zaborcami. Film ten prezentował panoramę wydarzeń z dziejów Polski, szczególnie eksponował powstanie kościuszkowskie i postawę Berka Joselewicza (w roku 1794 zorganizował on z ochotników żydowskich pułk lekkiej jazdy, większość z jego żołnierzy zginęła podczas obrony warszawskiej Pragi przed wojskami Suworowa, a on sam trafił do niewoli) i motywy związane z powstaniem styczniowym[9]. W lasach polskich wszedł jednak na ekrany w wersji ocenzurowanej, której zażądała $z$ tzw. względów obyczajowych (wątek romansowy) konserwatywna partia Agudas Isroel. Filmy wpisujące się w nurt patriotycznego kina polskiego po roku 1918 łączyła tendencja do ukazywania wspólnoty losów Żydów i Polaków, jak również przesłanie asymilatorskie[10]. Istotnym elementem kontekstu politycznego, w którym one powstały, było porozumienie sejmowego Koła Żydowskiego z rządem Władysława Grabskiego w roku 1925, a przede wszystkim - przewrót majowy w roku 1926 i dojście do władzy obozu piłsudczykowskiego, który chciał ułożyć stosunki z ludnością żydowską, opierając się na zasadzie asymilacji państwowej[11]. Premier Kazimierz Bartel zapowiedział walkę $\mathrm{z}$ antysemityzmem gospodarczym i zniesienie ograniczeń w zakresie równouprawnienia, pochodzących jeszcze z czasów zaborów. Okres stosunkowo pomyślnego rozwoju relacji polsko-żydowskich przerwała śmierć Józefa Piłsudskiego. W następnych latach w kinie jidysz do wątków asymilacyjnych już nie powrócono[12].

[8] Życie pod zaborami nie sprzyjało asymilacji, a gospodarcze zacofanie spowalniało akulturację. Zob. Najnowsze dzieje Żydów w Polsce, s. 90-91, 154; A. Landau-Czajka, Syn będzie Lech... Asymilacja Żydów w Polsce międzywojennej, Wydawnictwo Neriton, Instytut Historii PAN, Warszawa 2006.

[9] Po ucieczce z niewoli kilka lat służył on w Legionach. Natomiast w roku 1863 grupa galicyjskich Żydów przyłączyła się do powstańców. Zob. Najnowsze dzieje Żydów w Polsce; A. Żbikowski, op. cit., s. 67; R. Żebrowski, Dzieje Żydów w Polsce. Kalendarium, Żydowski Instytut Historyczny w Polsce, Warszawa 1993, s. 50, 70.
[10] Np. Na Sybir i Rok 1914 H. Szaro; Mogiła nieznanego żotnierza i Dziesięciu z Pawiaka R. Ordyńskiego; Krwawy wschód J. Nowiny-Przybylskiego; Gwiaździsta eskadra L. Buczkowskiego; Przeor Kordeckiobrońca Częstochowy E. Puchalskiego.

[11] Zob. Najnowsze dzieje Żydów w Polsce, s. 221, 223-224; A. Żbikowski, op. cit., s. 196.

[12] Andrzej Żbikowski zaznacza, że mimo wzrostu znaczenia postępowych środowisk żydowskich, to w międzywojniu ,akulturacja i modernizacja coraz rzadziej wiązały się z asymilacją" i z kulturą polską (A. Żbikowski, op. cit., s. 209). 
Nietypowym przykładem filmu żydowskiego, ze względu na język (w dialogach używano hebrajskiego, arabskiego i polskiego)[13], jest pionierska produkcja dźwiękowa realizowana w roku 1933 w Palestynie przez Aleksandra Forda. Miała być ona fabularnym (odosobnionym, gdyż tematycznie zbliżone projekty z tego okresu to filmy dokumentalne) nawiązaniem do tendencji syjonistycznej i problematyki odrodzenia państwa żydowskiego - Erec Israel oraz motywu powrotu doń[14]. Z powstawaniem filmu Sabra - fabularyzowanego dokumentu o życiu osadników pochodzących z żydowskiej diaspory w Polsce, w którym zagrali aktorzy słynnego teatru Habima - wiążą się pewne paradoksy. Praca nad zdjęciami poprzedzona była trwającą ponad pół roku peregrynacją po Palestynie reżysera, jego żony i operatora, podczas której rejestrowano dokumentalny materiał, częściowo wykorzystany w filmie; wtedy też krystalizowała się koncepcja fabularna[15]. Zastanawia fakt, że wspomniany operator - Niemiec Franz Xaver Weihmayr - był zarazem jednym $z$ autorów zdjęć do propagandowych nazistowskich filmów Leni Riefenstahl - Zwycięstwa wiary (1933) i Triumfu woli (1935)[16]. Był on też operatorem propagandowego filmu Hans Westmar (1933) [17]. Angażował się więc w tym okresie w przedsięwzięcia o zaskakująco różnej wymowie ideowej. Trudno jednoznacznie wnioskować o jego motywacjach, ważną cezurą w biografii tego operatora było jednak Z pewnością dojście Hitlera do władzy w roku 1933[18].

Drugi paradoks związany jest z poglądami reżysera. Intencją Władysława Markiewicza, kierownika produkcji i pomysłodawcy filmu o pionierach (przed emigracją do Palestyny kierował on w Polsce produkcją kilku filmów żydowskich i polskich), było ściągnięcie uznanego młodego reżysera w celu rozwijania żydowskiej kinematografii w Palestynie[19]. Ford podjął się tylko realizacji filmu Sabra, a jako reżyser o lewicowych poglądach usiłował nasycić go treściami społecznie postępowymi. Był on też zdystansowany wobec idei syjonistycznych i starał się balansować, kreując obraz, w którym miał skonfrontować ze sobą dwa wrogie światy - arabski i żydowskich pionierów. Pod wpływem producentów Ford zmienił wymowę ostatnich scen filmu (dokopania się do źródła wody, pozwalającego na koegzystencję wrogich

[13] Inny hebrajski tytuł - Chalucim - pionierzy. Producenci planowali hebrajską, polską i niemiecką wersję dźwiękową. Zob. N. Gross, op. cit., s. 56.

[14] Np. zrealizowany nieoficjalnie, bez ocenzurowania, film o wizycie w Polsce W. Żabotyńskiego - przywódcy Radykalnej Narodowej Organizacji Syjonistycznej, twórcy projektu masowej emigracji Żydów z Europy Środkowej do Palestyny. Ruch syjonistyczny podzielony na odłamy był bardzo popularny w międzywojennej Polsce. Zob. N. Gross, op. cit., s. 101-105, 110-111; Najnowsze dzieje Żydów w Polsce, s. 151, 218-219, 221-222, 227-228, 234-237; A. Żbikowski, op. cit., s. 202-204.

[15] Zob. N. Gross, op. cit., s. 50. Franz Weihmayr współpracował też z Józefem Lejtesem przy Dzikich polach (1932).

[16] Zob. R. Rother, Leni Riefenstahl. The Seduction of Genius, Continuum, London-New York 2002, s. 237-238.

[17] Film w reżyserii F. Wenzlera odwoływał się do postaci nazisty Horsta Wessela, autora pieśni uznanej po jego śmierci za nazistowski hymn.

[18] Możliwe, że usiłował on zatrzeć pamięć o udziale w realizacji filmu Leontine Sagan Dziewczęta w mundurkach (1931), który ze względu na wątek miłości lesbijskiej i krytykę pruskich metod edukacji był w III Rzeszy filmem zakazanym.

[19] Zob. N. Gross, op. cit., s. 49. 
nacji) i nadał pozytywny wydźwięk wątkowi miłości młodego osadnika i Arabki. Mimo przesłania wpisanego w koncepcję brytyjskich władz mandatowych, opartą na współpracy Żydów i Arabów, nie pozwolono na wyświetlanie filmu w Palestynie ze względów obyczajowych[20]. Film nie odniósł też spodziewanego sukcesu w Polsce, co wpłynęło zapewne negatywnie na decyzje o ewentualnych kolejnych projektach związanych z tą problematyką. Produkcje za granicą miały wyższe koszty, a kryzys gospodarczy nie sprzyjał podejmowaniu takiego ryzyka. Film Sabra reklamowany był w Polsce - prawdopodobnie głównie ze względów handlowych, a nie politycznych - jako „polsko-palestyński” film dźwiękowy, co sprawiało, że recenzenci z pism diaspory w kraju zarzucali dystrybutorom próby „odżydzenia”[21] go i zneutralizowania jego przesłania o odbudowie państwa w Palestynie. Reżyserowi usiłującemu zachować niezależność poglądów trudno było zadowolić środowiska syjonistów. Ruch ten - do którego rządzący obóz sanacji, blokujący rozwój organizacji nacjonalistycznych, także żydowskich, miał stosunek ambiwalentny - nie oddziałał więc silniej na międzywojenne kino jidysz w Polsce[22].

Kolejną dźwiękową produkcją realizowaną także przez Forda, już w jidysz i w zgodzie z jego przekonaniami, była Droga młodych (1936), według scenariusza działaczki komunistycznej Wandy Wasilewskiej i Jakuba Pata - członka Bundu, organizatora żydowskiego szkolnictwa świeckiego. Film fabularno-dokumentalny traktował o pobycie w Żydowskim Sanatorium Dziecięcym w Miedzeszynie grupy młodocianych podopiecznych, którzy przechodzą socjalizację i w wyniku uświadomienia społecznego interesują się losem dzieci górników. Obraz sfinansowany przez socjalistyczną partię żydowską Bund wpisywał się w lewicową i laicką tendencję[23]. Korespondował on też z postulatami filmu użytecznego społecznie Stowarzyszenia Miłośników Filmu Artystycznego „Start”, którego współzałożycielem był Ford. O zatrzymaniu Drogi młodych przez cenzurę i niedopuszczeniu do oficjalnych projekcji zdecydowały względy polityczne - zarzucano realizatorom, że propagują światopogląd komunistyczny i polecono wprowadzenie zmian, usunięcie wielu fragmentów. Producent - Zarząd Sanatorium im. Medema - nie zgodził się na to. Film pokazywano jednak na tajnych projekcjach (uczestnikiem jednej z nich był Antoni Słonimski), wysłano też jego kopię pod tytułem Nous arrivons na pokaz do Francji[24]. Lewicowość nie była typowa dla kina jidysz w Polsce między-

[20] Brytyjczycy prowadzili politykę ograniczania liczby imigrantów do Palestyny i szukania kompromisu $\mathrm{z}$ antyżydowskimi organizacjami arabskimi. Zob. Najnowsze dzieje Żydów w Polsce, s. 228.

[21] L. Strakun, za: N. Gross, op. cit., s. 56. Producenci nastawieni byli na sprawdzenie dochodowości dźwiękowca w wersji polskiej, gwarantującej większą publiczność (Polaków i Żydów).
[22] Zob. Najnowsze dzieje Żydów w Polsce, s. 234, 236-237.

[23] „Bund opowiadał się za budową systemu socjalistycznego, lecz od komunistów różniło go podejście do kwestii narodowej [...] oraz odrzucanie niektórych metod działania partii bolszewickiej, zwłaszcza dotyczących reprezentantów odmiennych poglądów" (Najnowsze dzieje Żydów w Polsce, s. 147).

[24] Zob. N. Gross, op. cit., s. 109-110. 
wojennej (ze względu na obowiązującą cenzurę i sytuację polityczną, związaną ze zwalczaniem przez rządzący obóz sanacji przeciwników politycznych)[25]. Znamionowała ona natomiast propagandowe filmy żydowskie powstałe w bolszewickiej Rosji, a następnie także w Związku Sowieckim (np. Towarzysz Abram, 1919; Krwawy potok, 1925; Powrót Natana Bekera, 1932)[26].

Dźwiękowa twórczość filmowa, nazwana „złotą erą” [27], która rozpoczęła się w roku 1936 i trwała do wybuchu drugiej wojny światowej, wyrastała przede wszystkim z tradycji religijnej, z języka jidysz i związanej z nim kultury, obyczajowości. Po roku 1929 zaniechano na ziemiach polskich produkcji w jidysz, głównie z przyczyn ekonomicznych (kryzys gospodarczy 1929-1935). Nowość techniczna, którą był dźwiękowiec, wymagała inwestycji, ale i czasu na wykwalifikowanie specjalistów. W czerwcu 1936 roku obniżono opodatkowanie krajowych filmów, co korzystnie wpłynęło na ich produkcję. Rozkwit kina „złotej ery” był jednak przede wszystkim nie tyle wynikiem rozwoju technicznego, ile raczej przejawem skonsolidowania twórców wokół idei odrodzenia kultury żydowskiej w obliczu zagrożeń i represji[28]. Środowisko filmowe funkcjonowało w społeczno-politycznej rzeczywistości drugiej połowy lat 30., którą znamionowały narastające przejawy antysemityzmu (ustawa ograniczająca ubój rytualny; getto ławkowe; ograniczenie dostępu do adwokatury; ekscesy bojówek nacjonalistycznych)[29]. Natan Gross pisał o obawach związanych z radykalnymi reakcjami i bojkotem przez polską publiczność kin prezentujących filmy jidysz, Jim Hoberman przywołuje wspomnienia Diny Halpern opisujące ekscesy towarzyszące produkcji Dybuka, a antysemickie wątki publikacji w prasie polskiej lat 30. na temat twórców i filmów jidysz badał Marek Halberda[30]. Należy jednak zauważyć, że w dwudziestoleciu nie powstał żaden film o wymowie antysemickiej, a w Polsce znaleźli schronienie artyści, których pochodzenie żydowskie narażało na prześladowania w nazistowskich Niemczech[31]. Pracowali oni nad otwierającym „złotą erę” filmem Za grzechy (1936) - m.in. reżyser Aleksander Marten, aktor Kurt Katsch, kompozytor Hanoch Kon i scenograf Jankiel Adler. Nie do przecenienia jest wkład w kinematografię międzywojnia osób pochodzenia żydowskiego. Filmy dla publiczności diaspory bywały efektem współpracy realizatorów żydowskich i pol-

[25] Zob. W. Śleszyński, Obóz odosobnienia w Berezie Kartuskiej 1934-1939, Dom Wydawniczy Benkowski, Białystok 2003.

[26] Zob. R. Włodek, op. cit., s. 16, 24-25.

[27] E.A. Goldman, op. cit., s. 83-110.

[28] Por. J. Hoberman, Bridge of Light: Yiddish Film between Two Worlds, Temple University Press, Philadelphia 1995, s. 276.

[29] Zob. Najnowsze dzieje Żydów w Polsce, s. 192-197, 207-211, 232.

[30] Zob. N. Gross, op. cit., s. 63-63; J. Hoberman, op. cit., s. 283; M. Halberda, „Swoi” $i$ „nasi”. Kwestia żydowska w publicystyce filmowej lat trzydziestych, „Iluzjon” 1988, nr 1, s. 5-55; A. Madej, Jest źle, ale musi być lepiej, „Kwartalnik Filmowy” nr 18, 1997, s. 205. [31] Zob. Najnowsze dzieje Żydów w Polsce, s. 197-199. Miało to związek z akcją wydalania z III Rzeszy pozbawionych mienia Żydów z obywatelstwem polskim (kilkadziesiąt tysięcy) i próbami przeciwdziałania jej przez polskie władze na drodze ustawy o pozbawieniu obywatelstwa osób przebywających za granicą. Ok. 6 tys. osób zatrzymano w obozie w pogranicznym Zbąszyniu, gdzie w prymitywnych warunkach oczekiwały na wynik rozmów polsko-niemieckich. 
skich, np. Judeł gra na skrzypcach oraz Błazen purymowy w reżyserii Józefa Greena i Jana Nowiny-Przybylskiego. Edward Zajiček ocenia, że wspólne działanie i konieczność pokonywania podobnych przeciwności sprawiały, iż w międzywojennym środowisku filmowym w Polsce nie zaznaczały się przejawy antysemityzmu[32].

Pomimo niesprzyjających uwarunkowań politycznych, ale i wbrew gustom części widzów, oglądających lekceważone przez krytyków amerykańskie produkcje w jidysz, tzw. szund, w filmowym kręgu żydowskiej diaspory narastała potrzeba tworzenia dzieł ambitnych, sięgających do źródeł tradycji żydowskiej. Odrodzenie kina jidysz okazało się też ważne dla publiczności, gdyż filmy kręcone przez Żydów dla Żydów wzmacniały tożsamość. Wywiedziony z biblijnej kondycji narodu wybranego i związany $\mathrm{z}$ niepewnością życia w diasporze motyw wędrówki, silnie obecny w żydowskiej literaturze, stał się jedną z głównych kategorii, wokół których budowano fabuły[33]. Postać posłańca, wędrowca (wysłańca zaświatów lub peregrynującego człowieka) i obraz gościńca, wątek przemierzania drogi występują w wielu filmach, różnych gatunkowo, np. w Dybuku, Ślubowaniu, Błaźnie purymowym, Judeł gra na skrzypcach, Liście do matki, Bezdomnych. Motyw tułaczki transponowany był też w wątek podróży za Ocean, uzasadniony charakterystycznym dla epoki zjawiskiem zarobkowej emigracji do USA [34]. Bohaterowie filmowi nawiązywali raczej do postaci z utworów Szolema Alejchema, kronikarza epoki industrializacji i sekularyzacji, niż do donkichotowskiego typu protagonisty Podróży Beniamina Trzeciego Mendele Mojcher Sforima zdążającego do Ziemi Obiecanej[35]. Wątek podróży za Ocean łączył się niekiedy z wyobrażeniem marzeń bohaterów o awansie, karierze na emigracji (Za grzechy; Judeł gra na skrzypcach, 1936). Temat migracji wiązano jednak przede wszystkim z przeciwstawieniem systemu wartości tradycyjnych żydowskich miasteczek - sztetli, i cywilizacji wielkomiejskiej, żądającej wyrzeczenia się tożsamości i więzi z bliskimi, prowadzącej do moralnego upadku (np. List do matki, 1938, w reż. Leona Trystana i nakręcona tuż przed wybuchem wojny przez Aleksandra Martena ekranizacja dramatu Jakowa Gordina Bezdomni).

Filmy te odwoływały się często do konwencji rodzinno-obyczajowej sagi, melodramatu rodzinnego, służąc kultywowaniu wartości tradycyjnej wspólnoty żydowskiej i jej scalającej mocy. Stąd też pozwalający na rozwiązanie intrygi wątek powrotu marnotrawnego

[32] Zob. E. Zajiček, Poza ekranem. Kinematografia polska 1918-1991, WAiF, Warszawa 1992, s. 19-20. Podobną tezę stawiają Natan Gross i Alina Madej, wiążąc ją z przenikaniem się kręgu tych samych producentów filmów dla publiczności polskiej i żydowskiej.

[33] Zob. M. Adamczyk-Garbowska, Odcienie tożsamości. Literatura żydowska jako zjawisko wielojęzyczne, Wydawnictwo UMCS, Lublin 2004, s. 22. O wątkach w kinie jidysz pisał też Lesław Czapliński. Zob.
L. Czapliński, Film żydowski w Polsce lat trzydziestych, „Kino” 1986, nr 5, s. 20-23.

[34] Emigracja zamorska, mimo restrykcji w obu Amerykach, związanych z chronieniem własnego rynku pracy, wynosiła w latach 1926-1937 ponad 190 tys. osób. Zob. Najnowsze dzieje Żydów w Polsce, s. 164 .

[35] Zob. M. Adamczyk-Garbowska, op. cit., s. 28-32, 36-37. 
członka rodziny. Powtarzająca się w kilku filmach (Dybuku, Ślubowaniu, Błaźnie purymowym, Liście do matki i Judeł gra na skrzypcach) perypetia odmieniająca bieg zdarzeń, polegająca na zrywaniu zaręczyn lub ślubu, wpisywała się w religijnie motywowane wyobrażenia o małżeństwie. Familijna opowieść miała też swoją wersję komediową. Była to Mateczka (1938) w reż. Konrada Toma i Józefa Greena z gwiazdą amerykańskiego kina i teatru jidysz - Molly Picon w roli dziewczyny troszczącej się o osierocone rodzeństwo, zrealizowana, podobnie jak Judeł gra na skrzypcach, także z Picon, głównie z myślą o żydowskiej publiczności w USA. Produkcje, które mogły być prezentowane widzom diaspory zarówno w kraju, jak i za Oceanem, były charakterystycznym zjawiskiem związanym $\mathrm{z}$ kinem jidysz w Polsce i miały związek z obsadzaniem aktorów znanych z filmów jidysz w USA, rozpoznawanych przez tamtejszą publiczność. Józef Green sprowadził do Polski także Miriam Kressin i Hymie Jacobsona (Błazen purymowy) oraz Mischę i Lucy Germanów (List do matki).

Obrazowanie tradycyjnej rodziny żydowskiej wiązało się też $\mathrm{z}$ inną kategorią kluczową dla konstrukcji filmowych opowieści - ze sztetlem i toczącym się w nim życiem (Dybuk, Weseli biedacy, Judet gra na skrzypcach, Błazen purymowy). Motyw ten miał swe źródła w literaturze żydowskiej[36]. Sztetl jest w filmach jidysz centrum i punktem wyjścia, z którego wyruszają i do którego tęsknią bohaterowie (na ekranie często pojawiał się Kazimierz nad Wisłą). Fabuły z wątkiem emigracji i te osadzone wyłącznie w żydowskim miasteczku pełniły funkcję terapeutyczną dla odbiorców i stanowiły wyraz tendencji eskapistycznej. Filmy te nie pozwalają w pełni zorientować się, że ich akcja toczy się w Polsce, najczęściej bowiem brak w nich polskich realiów [37]. Gross zwraca uwagę na unikanie aktualnej fabuły, która zmuszałaby do zajęcia stanowiska wobec zjawisk społeczno-politycznych (w filmach Judeł gra na skrzypcach, Za grzechy, Bezdomni, Dybuk, Ślubowanie akcja rozgrywa się w okresie mniej więcej pierwszej wojny światowej)[38]. Ciekawym kontekstem dla tej tendencji jest wypowiedź Józefa Relidzyńskiego, naczelnika CBF, z lutego 1939 roku: „filmy produkowane w Polsce w języku żydowskim oddają rzeczywistość żydowską w świetle właściwym, tj. ciepłym, i należałoby sobie życzyć, aby filmy polskie tę rzeczywistość polską co najmniej równie dobrze reprezentowały" [39]. Sztetl w filmach jidysz kręconych w okresie „złotej ery” na ogół jest miejscem mitycznym, postrzeganym pozytywnie i chętnie idealizowanym. Wyobrażenia takie łączą się raczej z literacką wizją z utworu Szaloma Asza - tytułowego miasteczka jako sielankowej enklawy, niż z krytycznymi obrazami biedy i zaniedbania kreowanymi przez Icie Mejera Weissenberga[40].

[36] Zob. ibidem, s. 20.

[37] W Judeł gra na skrzypcach padają dwa zdania po polsku. Zob. R. Włodek, op. cit., s. 48.

[38] Zob. N. Gross, op. cit., s. 83.

[39] Komunikat prasowy Zwiazku Dziennikarzy i Publicystów Filmowych o konferencji w Ministerstwie Spraw Wewnętrznych $w$ sprawie tematyki filmowej krajowej produkcji, „Aktualności” 1939, nr 1.

[40] Zob. M. Adamczyk-Garbowska, op. cit., s. 2o-21. 
Niektóre z produkcji łączył też inny element związany z tradycją literacką diaspory. W filmowym pejzażu sztetlu występowały niekiedy postaci, których cechy stanowiły nawiązanie do charakterystycznej, zaczerpniętej z folkloru i obecnej w literaturze żydowskiej, figury szlemiela - nieudacznika, naiwniaka, źle traktowanego przez otoczenie (np. Bońcie milczek Icchoka Lejba Pereca)[41]. Filmowe wcielenia szlemiela miały rys filozoficzny (Błazen purymowy) lub zdecydowanie komiczny (para przyjaciół w Wesołych biedakach grana przez aktorów kabaretowych Szymona Dżigana i Izraela Szumachera) bądź też odwołujący się do popularnej w teatrze żydowskim tradycji przebieranek[42], jak w kreacji utalentowanej muzycznie dziewczyny noszącej strój chłopca, którą grała w Judeł gra na skrzypcach Picon[43].

Filmowe opowieści obrazują jednak przede wszystkim unicestwiony przez Zagładę tradycyjny świat żydowski. Świadczą one o zanurzeniu egzystencji mieszkańców sztetli w obrzędach i formach religijności, a także o organizacji codzienności wg rytualnego kalendarza żydowskiego. Tendencja ta stanowi też jeden $\mathrm{z}$ elementarnych motywów literatury żydowskiej[44]. W powstałych na ziemiach polskich filmach utrwalone zostały obyczaje i święta religijne - np. przedstawienia purimowe (Błazen purymowy); tradycje weselne (Dybuk; Judeł gra na skrzypcach); nigun - tradycja śpiewu chasydów na dworze cadyka (Dybuk); święta Rosz Ha-Szana i Jom Kipur (Za grzechy); Sukot (Mateczka; Dybuk); Pesach i wieczerza sederowa (List do mat$k i$ ). Dzięki obyczajowo-religijnym odniesieniom filmy jidysz mogły służyć potwierdzaniu i scalaniu żydowskiej tożsamości. Natomiast, jak przypomina Żbikowski, historycy nie są zgodni, „,o zdecydowało, że większość polskich Żydów, w przeciwieństwie do francuskich czy niemieckich, pozostała wierna ortodoksyjnej tradycji religijnej, często bliższej wzorcom średniowiecznym niż nowoczesności”[45].

Śladem tego jest także forma filmowej przypowieści Ślubowania (1937) w reżyserii Henryka Szaro i Dybuka (1937) w reżyserii Michała Waszyńskiego. Wpisuje się w nią zespół elementów nawiązujących do żydowskiego mistycyzmu, wątków chasydzkich, kabalistycznych oraz wierzeń ludowych. Struktura filmowej przypowieści ma swe źródło w mocnym osadzeniu kultury żydowskiej w słowie i tendencji do ukazywania świata w nawiązaniu do innej wcześniejszej opowieści[46]. Film Waszyńskiego, którego scenariusz oparty był na mistycznym dramacie Na pograniczu dwóch światów. Dybuk Szymona An-skiego, stanowi

[41] Zob. ibidem, s. 21-22, 41-42.

[42] Zob. R. Włodek, op. cit., s. 38. Wynikało to z genezy tego teatru związanej z przedstawieniami purimowymi i zwyczajem przebierania się w święto Purim w stroje innej płci. Zob. A. Unterman, $Z \dot{y} d z i$. Wiara i życie, tłum. J. Zabierowski, Wydawnictwo Łódzkie, Łódź 1989, s. 227.

[43] Kreacje tej aktorki, oparte często na męskim przebraniu i przełamujące tradycyjne kobiece role, są współcześnie interpretowane jako transgresyjne wcielenia chłopczycy czy wprost chłopca (Judeł gra na skrzypcach). Zob. E. Sicular, Gender Rebellion in Yiddish Film. Molly Picon, w: When Joseph met Molly, red. S. Paskin, Five Leaves, Nottingham 1999, s. 245-254.

[44] Zob. M. Adamczyk-Garbowska, op. cit., s. 17-18. [45] A. Żbikowski, op. cit., s. 213.

[46] Zob. M. Adamczyk-Garbowska, op. cit., s. 16-17. 
najwybitniejsze osiągnięcie międzywojennego kina jidysz[47]. Oba filmy łączy zaś postawa realizatorów - rezygnacji z opisu współczesności i świadomego zwrotu ku archaicznej przypowieści, ku wierze w ingerencję sił nadprzyrodzonych w doczesności. Elementem wspólnym, stanowiącym motywację akcji w tych filmach, jest oparcie się na odwołaniu do talmudycznej przypowieści o przeznaczeniu kobiety mężowi na 40 dni przed jej narodzeniem oraz na wątku obietnicy zaprzyjaźnionych ojców - połączenia ślubem ich przyszłych dzieci. Rozwojem wydarzeń w obu filmach kieruje wszechmocne przeznaczenie, nad jego wypełnieniem czuwają wysłannicy zaświatów - Posłaniec Meszulach w Dybuku, prorok Eliasz korygujący decyzje śmiertelników i gwarantujący ład w świecie przedstawionym w Ślubowaniu. Wątki te mogły budzić w odbiorcach odczucie pocieszenia i utwierdzać ich w eskapistycznej reakcji na narastające poczucie zagrożenia, ale zarazem kwestia przewagi duchowości nad cielesnością pozwalała żydowskim widzom nie tylko neutralizować dramatyzm doczesnego doświadczenia, ale też uprawomocnić sens własnej religijnej wizji świata.

Kinematografia jidysz na ziemiach polskich kształtowała się pod wpływem czynników społeczno-politycznych i kulturowych tendencji. Zmiany zachodzące w niej od jej początków po wybuch drugiej wojny światowej stanowiły często odpowiedź na kontekst zewnętrzny. Zaznaczyło się to bardzo wyraźnie jako wstrzymanie twórczości w czasie pierwszej wojny światowej i w pierwszych latach niepodległej Polski z przyczyn politycznych, ale też jako zaprzestanie krajowej produkcji w jidysz w okresie kryzysu gospodarczego lat 1929-1935. Zewnętrzne uwarunkowania miały również wpływ na objawienie się w drugiej połowie lat 20. filmowego śladu tendencji asymilacyjnej. Natomiast niezwykle wyrazistym i oryginalnym przejawem odpowiedzi na kontekst społeczno-polityczny epoki była twórczości tzw. złotej ery, wyrastająca z szerszego zjawiska odrodzenia kultury żydowskiej jako odpowiedzi na narastające w drugiej połowie lat 30. poczucie zagrożenia. Świat przedstawiony w filmach jidysz kształtował się w wyniku napięcia pomiędzy zewnętrznym społeczno-politycznym kontekstem a wewnętrznymi tendencjami w środowisku diaspory. Efektem tego było osłabione i incydentalne oddziaływanie na kino jidysz w Polsce tendencji syjonistycznej, jak również związanej z lewicą - Bundem. Spośród hermetycznych kulturowo-ideowych uwarunkowań największy wpływ na problematykę i formułę kina żydowskiego na ziemiach polskich, od jego początków po wybuch drugiej wojny światowej, miała tendencja tradycyjna, odwołująca się do judaizmu i języka jidysz. Zakorzeniony w niej zespół motywów, wątków tematycznych, schematów fabularnych miał swe odpowiedniki także w twórczości literackiej diaspory. 